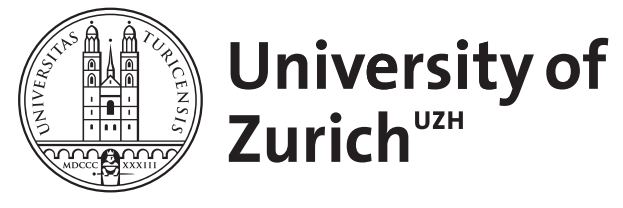

\title{
Foreword by Daniel Thürer
}

Thürer, Daniel

\begin{abstract}
Fifty years ago ... on 10 December 1948, the General Assembly of the United Nations solemnly adopted the Universal Declaration of Human Rights. This event was a turning point in the development of international law. The individual human being, whose rights had been established over the long evolution of constitutional history, was now recognized as a central point of reference within the international legal system
\end{abstract}

DOI: https://doi.org/10.1017/s0020860400091208

Posted at the Zurich Open Repository and Archive, University of Zurich

ZORA URL: https://doi.org/10.5167/uzh-154552

Journal Article

Published Version

Originally published at:

Thürer, Daniel (1998). Foreword by Daniel Thürer. International Review of the Red Cross, 38(324):406407.

DOI: https://doi.org/10.1017/s0020860400091208 


\section{Foreword by Daniel Thürer}

Fifty years ago ... on 10 December 1948, the General Assembly of the United Nations solemnly adopted the Universal Declaration of Human Rights. This event was a turning point in the development of international law. The individual human being, whose rights had been established over the long evolution of constitutional history, was now recognized as a central point of reference within the international legal system.

Thirty years ago ... at the International Conference on Human Rights held in Teheran in 1968 to commemorate the Universal Declaration, a resolution was adopted on "Human rights in armed conflict". By shedding light on the rules and principles of international humanitarian law, the United Nations clearly revealed a line of thought much older than its own human rights law. As a matter of fact, Jean Pictet rightly observed that as long ago as 1864, with the adoption of the first Geneva or "Red Cross" Convention, an era which gave primacy to the individual and to the principles of humanity had already begun.

Today... we are witnessing an increasing tendency for the two traditions - human rights law and the law of armed conflict - to converge:

- in most modern armed conflicts both sets of rules are applicable, sometimes in a complementary way, but more usually in parallel;

- there is a growing understanding that international humanitarian law is to be interpreted in the light of human rights law, and vice versa;

- a general awareness is emerging among international lawyers that the two systems of rules are mutually supportive;

- although international law has established different mechanisms for the implementation of international humanitarian law and for that of human rights law, more and more often the two sets of rules are applied or referred to interchangeably. 
Thus we are on the threshold of fascinating new developments: international human rights law and humanitarian law, while remaining distinct, are in the process of drawing closer together. Undoubtedly, therefore, the theme of this issue of the International Review of the Red Cross is as apt as it is timely.

\section{Daniel Thürer \\ Professor, University of Zurich \\ Member of the ICRC}

